\title{
FACTORS ASSOCIATED WITH QUALITY OF LIFE IN THE PERSPECTIVE OF THE ELDERLY CAREGIVER WITH ALZHEIMER'S DISEASE
}

\author{
FATORES ASSOCIADOS À QUALIDADE DE VIDA NA PERSPECTIVA DO \\ CUIDADOR DE IDOSO COM A DOENÇA DE ALZHEIMER
}

\begin{abstract}
Clélia Santana Reis DAMÁSIO ${ }^{1}$; Adélia Dalva da Silva OLIVEIRA ${ }^{2}$; Ana Maria Ribeiro dos SANTOS ${ }^{3}$; Camila Aparecida Pinheiro Landim ALMEIDA ${ }^{4}$

1. Graduação em Gerontologia, Mestre em Saúde da Família, Centro Universitário UNINOVAFAPI. cleliamsreis@hotmail.com; 2. Enfermeira, mestre em Políticas Públicas pela Universidade Federal do Piauí, Doutor em Políticas Públicas pela Universidade Federal do Piauí e Pós-Doutora em Enfermagem pela Universidade de São Paulo; 3. Enfermeira, Mestre em Enfermagem pela Escola de Enfermagem Anna Nery, Doutora em Ciências pela Escola de Enfermagem de Ribeirão Preto da Universidade de São Paulo; 4. Enfermeira, Mestre em Enfermagem e Doutora em Ciências pela Escola de Enfermagem de Ribeirão Preto da Universidade de São Paulo.
\end{abstract}

\begin{abstract}
This study aimed to know the factors associated with quality of life (QOL) of elderly caregivers diagnosed with Alzheimer's disease from the perspective of these individuals. It was a descriptive study with qualitative approach based on the Collective Subject Discourse method. Twenty elderly caregivers diagnosed with Alzheimer's disease participated, during a month, in the period the month September 18 to October 18, 2017. Data collection was done through interviews with caregivers of elderly with Alzheimer's disease. The questions were asked and recorded on tape recorder, with the permission of the interviewee. Data were analyzed by the Descending Hierarchical Classification (DHC). Five classes were obtained: Quality of life concept for the elderly caregiver; Behavior of the elderly with Alzheimer; Memory problems in the elderly and repercussions on the caregiver's work; Change in family caregiver lifestyle; and Repercussion of "being a caregiver" in the quality of life. QOL was related to a range of factors (emotional, physical, financial, disease state in the elderly and the degree of knowledge of the caregiver about the disease). Caregivers have pointed out that non-harmony between these factors can be crucial to affect your personal and professional life as well as your QOL.
\end{abstract}

KEYWORDS: Alzheimer. Caregivers. Elderly.

\section{INTRODUCTION}

With the aging process, the human being becomes susceptible to the emergence of chronic non-communicable diseases (CNCD), of which Alzheimer's disease (AD) is distinguished, associated with approximately $70 \%$ of dementia cases in elderly people (WHO, 2012).

$\mathrm{AD}$ is characterized as a degenerative, progressive and irreversible neurological disease that progressively deteriorates the cognitive level of the individual, and later the functioning of the whole organism (CARVALHO, NERI, 2018; ILHA et al., 2017). Poor communication can have a particularly profound effect on the lives of people with dementia as it affects their ability to interact socially, maintain relationships, plan daily activities and express basic needs and thoughts to those around them (WOODWARD, 2013).

This condition accounts for about $50 \%$ of dementia cases in the United States and Great Britain and is estimated to be the fourth leading cause of death in the elderly in these countries. The course of the disease ranges from 5 to 10 years and the reduction in life expectancy is around $50 \%$. In addition, the disease has no cure and no treatment, effective enough to prevent its evolution (WHO, 2012; ALMEIDA; GOMES; NASCIMENTO, 2014)

With the evolution of the disease, the elderly person depends on continuous care, performed in most cases by a family member at home. Care for the elderly person with $\mathrm{AD}$ becomes very complex, as the family perceives themselves involved in feelings that are difficult to manage, which end up imposing social isolation on them, profoundly shaking the emotional systems, leading to deprivations and changes in lifestyle (SEIMA; LENARDT; CALDAS, 2014).

This dependence of the elderly with AD demands factors that influence the QoL of the family caregiver that can be grouped in the following aspects: depression; poor sleep quality; type of dementia and neuropsychiatric symptoms; support, social support and access to health services; recreation; pre-existing health problems; subsidized 
interventions with caregiver training and spirituality (PEREIRA; SOARES, 2015).

$\mathrm{AD}$ is considered the most common form of dementia among the elderly, accounting for 60 to $70 \%$ of cases (ADI, 2015). The worldwide incidence of $\mathrm{AD}$ is $3 \%$ of individuals aged between 60 and 65 years, and about $30 \%$ in individuals aged eighty or more (IBGE, 2011). It is estimated that there are around 35.6 million people with Alzheimer's disease in the world. In Brazil, there are about 1.2 million cases, most of them still undiagnosed (PRINCE et al., 2014) and every year about nine million new cases happen, according to the World Alzheimer Report (WHO, 2010).

A study conducted in Brazil identified high workload scores for caregivers when compared to caregivers in Spain. The different factors associated with this burden involve sociodemographic, clinical, and cultural aspects of the caregiver and patient, such as gender, relationship type, and neuropsychiatric symptoms (SOUSA et al., 2016).

The present study is justified by considering Alzheimer's disease as one of the important public health problems, due to the complexity of its clinical manifestations, requiring supervision, thus representing a great challenge for the caregiver of the elderly affected by the disease. The diagnosis of dementia has a severe impact on the lives of patients and families.

The prospect of change in the personal life and the people surrounding the patient is of such magnitude that making receiving the news of the disease a very difficult situation to accept. Negative emotional reactions involving impotence, fear and anger are common, as well as a deep sense of injustice.

Lack of information about the disease and treatment possibilities feed skewed beliefs based on stereotypes that often scare the wrong association of Alzheimer's disease with the end of relationships. Thus the study becomes relevant to reflect and seek to know the factors related to the quality of life of the caregiver of elderly with Alzheimer's, as it is an emerging disease and a public health problem, knowing the factors related to the quality of life of the caregiver, Health professionals will be supported to develop public policies and models of health care for this individual.

Based on the above, this study aimed to know the factors related to the quality of life of the caregiver of the elderly diagnosed with Alzheimer's disease from the perspective of this individual.

\section{MATERIAL AND METHODS}

Descriptive study of a qualitative approach, performed at an Integrated Health Center, located in a capital of the brazilian Northeast, considered a reference hospital for the diagnosis and treatment of Alzheimer's Disease in the Unified Health System (SUS). The Integrated Health Center has an Alzheimer's treatment program that works every Monday, an average of 10 appointments per week are scheduled for patients with suspected or diagnosed Alzheimer's, these consultations focus on one day, every Monday. Data collection was performed during 1 month from September 18 to October 18, 2017.

Included in the study were the caregivers of elderly people diagnosed with Alzheimer's disease who are treated at the Center aged 18 years or older. Participated a total of 20 caregivers were included in the waiting list for a consultation with the Center's neurologist during a month, this number of caregivers was defined through the process of saturation of speech.

The recruitment was done in person, waiting for consultations with the neurologist of the reference hospital in the treatment of Alzheimer's disease in the State of Piaui. Feedback for respondents was given through a video distributed in $\mathrm{CD}$ format explaining how to deal with the elderly with $\mathrm{AD}$ in their daily lives (bathing, eating, changing clothes, as well as cognitive stimulation activities for the elderly and how to alleviate the burden of caregiver care).

The data were produced after approaching and confirming the inclusion and exclusion criteria, the objectives of the research were explained and after signing the Informed Consent Term, the caregiver and the researcher went to an office and some questions were asked about the caregiver's profile, such as: age, sex, profession, income, schooling and the degree of kinship with the patient diagnosed with Alzheimer's disease, in two (2) questions concerning the caregiver's quality of life : a) What do you think quality of life means? b) Does the care of the person with Alzheimer's affect their quality of life? Talk freely about it. The interviews semi-structured- were recorded and later transcribed by the researcher. Each interview was conducted by the researcher in a reserved room of the institution and had an average duration of 30 minutes.

The concept of quality of life adopted in this study was that of the World Health Organization (WHO), which describes it as the individual's perception of their position in life, in the context of the culture and value systems in which they live and in relation to their goals, expectations, standards and 
concerns. This definition includes six main domains: (1) physical health, (2) psychological state, (3) levels of independence, (4) social relationship, (5) environmental characteristics, and (6) spiritual standard. (WHOQOL, 1995).

Statements were grouped and formed a corpus, which had statistical treatment in the software IRaMuTeQ (acronym of Interface of Routles Analyses Multidimensionelles de Textes et de Questionnaires) (OLIVEIRA et al., 2017), and were later analyzed by the Descending Hierarchical Classification (CHD) (MATOS et al., 2018a). The use of software has helped to apprehend the research object in the qualitative approach, with IRaMuTeQ being a highlight among them in recent years (QUEIROZ, SOUSA, 2017; RODRIGUES et al., 2017; MATOS et al., 2018b; QUEIROZ et al, 2018).

Thus, the data produced by the software generated segments of classes, which were denominated "pre-classes". These included segments of text with vocabulary similar to each other, but at the same time different from the text segments of the other classes. Then, key expressions were extracted from the interviewees' discourses, which complemented the CHD findings and allowed the delimitation of the discourses in "central ideas", according to previous studies (RODRIGUES et al., 2017; SOUSA et al., 2016; COUTO; CASTRO; CALDAS, 2016).

The analyzes resulting from the two treatments were based on the Collective Subject Discourse (DSC) method. It is a technique of tabulation and organization of qualitative data, developed by Lefevre and Lefevre (LEFEVRE; LEFEVRE, 2003a) which is based on the theory of Social Representation. The DSC is a synthesis discourse elaborated with parts of discourses of similar meaning, through systematic and standardized procedures (LEFEVRE; LEFEVRE, 2013b). This method allows verbal descriptions or empirical data to be organized, and collective thinking drawn from categories grouped into categories derived from the key expressions taken from the interviewees' discourses (classes and preclasses).

The study was approved by the Research Ethics Committee and followed national and international health research standards. To maintain the anonymity of the respondents, these were named according to the number of each subject searched.

\section{RESULTS}

Predominant individuals were informal or family caregivers, with a mean age of 51 years and female caregivers of the father or mother earning up to 1 minimum wage and up to 11 years of schooling.

Regarding the statements processed, IRaMuTeQ recognized the separation of the corpus in 126 Units of Elementary Contexts (UCE) and five classes, with a use of $75.9 \%$. The corpus was divided into two axes: The first, contemplated by classes 3, 2 and 4. The second sub-division of the body gave rise to class 5 , overlapping the previous ones with. Finally, class 1 appears encompassing all the other (Figure 1)

Through the descending hierarchical classification, it was possible to identify and analyze factors related to QoL, named in their respective senses in the five classes obtained in the dendogram. These classes formed the central ideas of the DSC (Table 1).

\section{IC 5 - Concept of quality of life for elderly caregiver}

It is noticed through the discurse of the caregivers that the quality of life is anchored in dimensions, covering Housing, Leisure, Humor, Physical health, Family, friends, among others. Caregivers, while generalizing the QoL to basic and daily activities, reveal that they can see it with the simplicity of living day to day in harmony. Resulting in this discourse:

"Quality of life is to be able to take good care of the elderly with Alzheimer's, giving him a balanced diet, his medicines at the right time, hygiene, decent housing, having income to bear all the costs, is treating him with good humor and comfort. This makes me very satisfied, to be able to take care with dignity. For me to have a quality of life, I need to live well, sleep in peace, work normally, have a good home, have leisure and money for my needs, time for myself, family and friends and have a normal life, health." (C2; C4; C9; C10; C13; C14; C15)

One sees an association with a "live well", characterized by them as a "normal course" of life, and strongly linked to the absence of disease, a simplistic view. At the same time, the participants admit that although having a good quality of life is a personal choice, its execution does not depend solely on who chooses it and is influenced by the environment where it is found. 


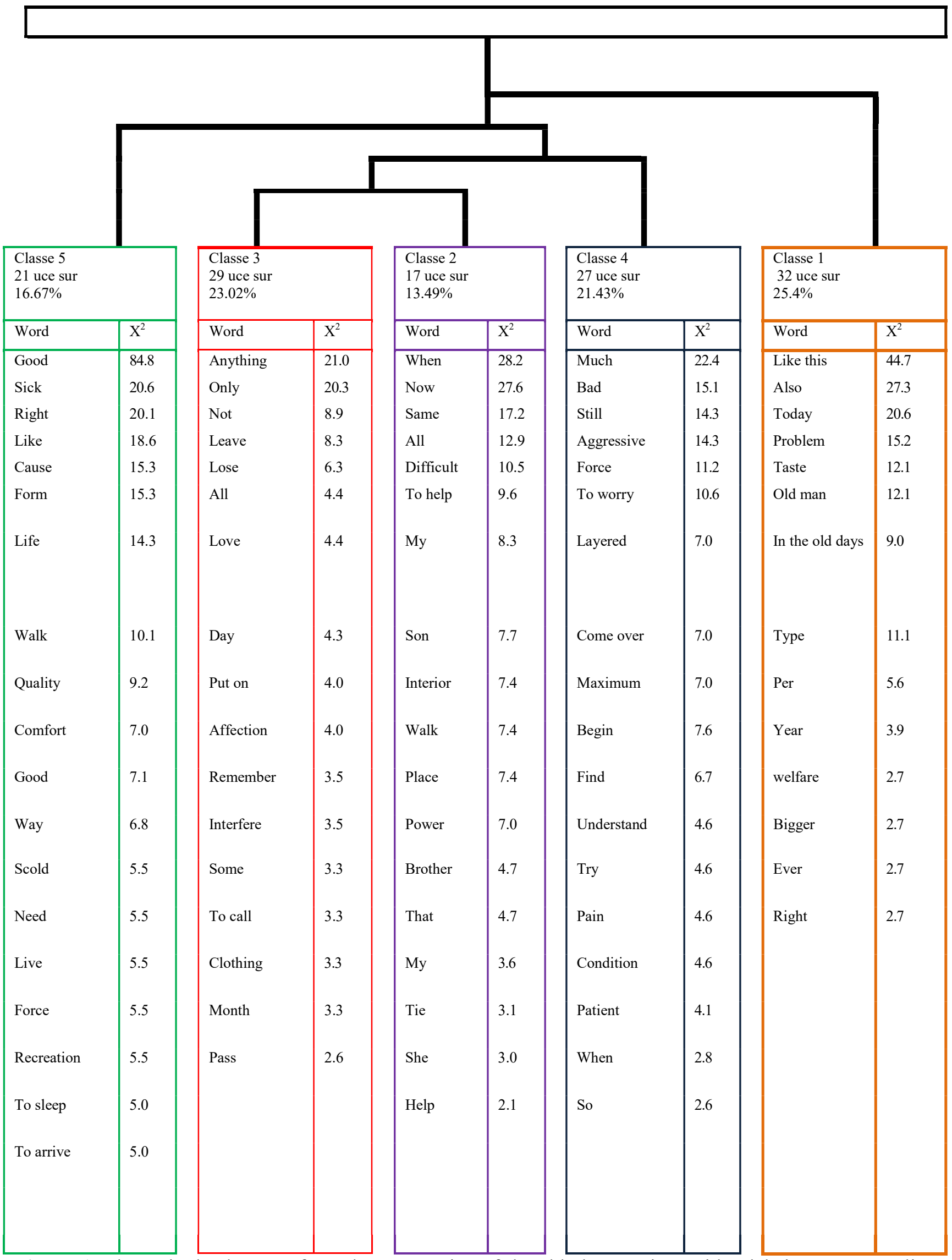

Figure 1. Thematic dendrogram from the perspective of the elderly caregiver with Alzheimer's on Quality of Life 
Table 1. Central Ideas of the five classes obtained in the dendogram

Central Idea (CI) 5 - Concept of quality of life for the elderly caregiver

$\mathrm{C} 2 ; \mathrm{C} 4 ; \mathrm{C} 9 ; \mathrm{C} 10$;

Central Idea (CI) 4 - Behavior of the elderly with Alzheimer's

$\mathrm{C} 13 ; \mathrm{C} 14 ; \mathrm{C} 15$

C3; C6; C8; C9;

$\mathrm{C} 14 ; \mathrm{C} 15 ; \mathrm{C} 16$

Central Idea (CI) 3-Memory problems in the elderly and repercussion in the caregiver's work

$\mathrm{C} 1 ; \mathrm{C} 5 ; \mathrm{C} 7 ; \mathrm{C} 8$;

C9; $\mathrm{C} 12 ; \mathrm{C} 19$;

Central Idea (CI) 2 - Change in family caregiver lifestyle

C9; C15; C16;

$\mathrm{C} 17 ; \mathrm{C} 19$

Central Idea (CI) 1 - Repercussion of "being a caregiver" in quality of life

Note: C: Caregiver(C).

\section{4 - Behavior of the elderly with Alzheimer}

As SEEN in the previous class, caregivers associate a good quality of life, there is a quiet day to day life. Thus, stressors can be defined as challenges to quality of life, of which the problems of the elderly are highlighted, especially regarding the behavior of the elderly with Alzheimer's. Caregivers tended to reconcile the diagnosis with behaviors, which tend to become more extreme over time. It is necessary that the caregiver knows the symptoms and the evolution of the disease to know how to act.

The discourses explicited the concerned about seeking information about the disease, understanding the symptoms, the physical and mental changes so that they can identify evolution and prepare in a creative way for care. Resulting in this discourse:

"It is difficult to live with the elderly diagnosed with Alzheimer's, you will have to learn to deal with the patient's physiology to know what is a symptom of the disease, to know that he is aggressive or with memory loss because of the disease, to know when he is feeling pain. The elderly need care 24 hours, he takes a lot of his time, because I need to give medication, bath, food, I have to do everything. I get very tired because the old man does not sleep and he does not let me sleep, he does his needs in the wrong place, I mess up what I say and he says he's fixing it, I need a lot of patience, the old man gets very aggressive and before he beat me a lot, now with the remedy he has improved, more it is necessary to have much knowledge and calm." (C3; C6; C8; C9; C14; C15; C16)

\section{3 - Memory problems in the elderly and repercussions on the caregiver's work}

This CI has content closely linked to CI 4, and CI 2. It was noticeable that the behavior of the elderly is a factor challenging the quality of life of the caregiver, and one of the reasons that causes the elderly to be more aggressive behavior are memory problems.

Memory loss in the elderly is the most prominent symptom of Alzheimer's disease and causes greater disruption to the caregiver's life. Work becomes more arduous, as this loss has a major impact on the Daily Life Activities (ADLs) and Instrumental Life Activities (AVDIs), the dependence of the elderly is a challenge and the caregivers reported a time restriction for activities and live exclusively for the sick person. Resulting in this discourse:

"The elderly with Alzheimer's have many memory problems, nowadays it depends on a person for everything, to take him to cut hair, to take a shower, to give food, to wear clothes, he does not know anything else, I try brush his teeth and he does not leave, I want to wash his face and he does not let me, just leave his hands. I have to go out to work, but when I do not have anyone to leave the elderly I can not leave, I can not go to work, because I can not leave him alone for a minute if I do not put the clean clothes for him to wear he wears the same clothes that were dirty, it's time that I feel overwhelmed, but I'm glad to be alive". (C1; C5; C7; C8; C9; C12; C19;)

\section{2 - Changing the family caregiver's lifestyle}

Another factor stressing the caregiver is the need for a change in the caregiver's lifestyle, which is why CI 2 is linked to 4 . The impossibility of curing the disease and the progressive development generate fear and changes in the family caregiver's lifestyle, bring in their speeches the changes in family life, changes in the dynamics and financial burden, the tendency to isolation and decrease of social support network, those who assume the mission of caring end up having a wear and tear that interferes directly with the quality of life. Resulting in this discourse: 
"It is difficult, very difficult to care for an elderly person with Alzheimer's, and I take care with pleasure because he is my relative and I can not despise, but I feel very overwhelmed, I do not want to leave anymore, because I can not leave him or take him with me, sometimes another family member stays with him, but I can not relax, I keep thinking about the work he is giving, what he may need and I do not want to disturb others. I paid a person to help me switch to showering, going to the bathroom, put in bed, but it is very difficult. Besides, he is very aggressive, at first I rebounded, but later I understood that it was a symptom of the disease. I realize that he feels a lot of pain but can not communicate and I need to know well and guess when he is in pain when it is a delusion. I need to take care of myself, because I feel a lot of pain, but it's difficult." (C9; C15; C16; C17; C19)

\section{1 - Repercussion of "being a caregiver" in quality of life}

Finally, CI 1 arises by grouping all the others and making a meeting of the challenges of caring for the elderly with Alzheimer's disease and the repercussions on the quality of life. The impact on the life of care is such that the barrier between the patient's life and that of care becomes diminished or ceases to exist and the caregiver starts to live in function of the behavioral changes of the elderly, which causes the sense of freedom, moments of chronic stress and physical overload. Resulting in this discourse:

"Being an elderly caregiver with Alzheimer's has a lot of repercussions on my quality of life, although I take care with pleasure because he is a very dear family. I dedicate all my time to him, he has to be very careful, because any carelessness he does something that does not I'm afraid he'll fall, burn, leave home alone, it's a lot to worry about, besides having to bathe, change, feed, assist in all activities of daily living, give medicine and he Most of the time he's angry, cursing, and trying to beat me up. It's a lot of stress, he does not sleep right and does not even let me sleep, when I can not sleep right I get very angry, very tired, I have my problems too and I can not solve them, because the elderly with Alzheimer's takes almost all my time." (C1; C4; C9; C10; C11; C18; C20)

\section{DISCUSSION}

The quality of life of caregivers of elderly people with Alzheimer's disease was related to emotional, physical, financial factors, disease state in the elderly - initial or advanced - and the degree of knowledge of the caregiver about the disease, and it was altered among the participants. Deficits in the caregiver's quality of life have shown great potential to compromise the care provided.

The care for elderly people at home due to their impossibilities is an important and vertiginous phenomenon in Brazilian society, intensifying since the beginning of the year 2000 in conformation with the phenomenon of population aging and increase of non-communicable chronic diseases (DCNTs). Thus, these diseases are related to increasing functional decline, loss of autonomy and independence, limitation of the capacity for selfcare and impairments in quality of life, which generate dependency relations that interfere in the processes of social interaction of the elderly (LEFEVRE; LEFEVRE, 2013b).

In the study the caregivers reported that the elderly are dependent to different degrees, the most independent - classified as the first phase of the disease, mild phase - in which the elderly are distracted, have difficulty remembering names, words and numbers, learning new things, have disorientation in the family environment and the reduction of social activities, the behavioral changes of the elderly generate worry and fear in the caregiver, who now devotes more of his time to the care of the elderly, since the elderly no longer perform their instrumental activities alone, the caregiver afraid of leaving the home and getting lost, and the worsening of the disease.

The elderly classified as moderate are already dependent on their caregivers, as the elderly have marked loss of memory and cognitive functions, deterioration of verbal skills, behavioral changes, delusions, hallucinations, inability to socialize, home, beginning of loss of sphincter control, thus becoming more dependent to also develop their activities of daily living and making care more arduous emotionally and physically.

The elderly classified as in the advanced stage of the disease are even more dependent on the caregiver, since the tendency of the speech disappears, making communication difficult, since the elderly feel pain and wants and can not communicate with the caregiver, in addition to continuing the delusions and hallucinations, behavioral disorders, there is loss of control of the bladder and intestines and the elderly person starts using geriatric diapers and may have to have probes, the tendency is for the elderly to stay bedridden and have difficulty swallowing food, requiring a probe for feeding.

To relieve the stress of the caregiver and improve his quality of life the caregiver must know 
the symptoms of the illness, usually he seeks information and support with the health teams. The team should be trained and understand that the caregiver is of the utmost importance, for this the gerontological care must be of quality, valuing the context in which the elderly lives and what support networks they have and how they integrate. It should also understand the various actors involved, ie, the elderly, family, caregiver (if any), community and health care teams. These should act in an interrelated way and with the focus on paid care, such as one that respects individuality, autonomy and that maintains or maximizes the independence of the elderly (PROCHET; SILVA, 2011).

In the research developed, with regard to the profile of caregivers, our results showed a predominance of female individuals (95\%) and family caregivers $(95 \%)$, results corroborated by similar texts, it was still observed a predominance of caregivers with low educational level 35\% studied 4 years or less and none of them had a higher education, low financial power was still perceived, with a maximum income of 2 minimum wages. Research carried out in Italy also showed that $80 \%$ to $90 \%$ of the caregivers were relatives of the elderly, $70 \%$ of them being female (CENSIS, 1999). Caring for the elderly with AD requires the physical and psychological care of the caregivers, especially if the patient has incapacitating diseases that increase their dependence, so it is necessary to take into account issues of ergonomics and their relationship with the caregiver's quality of life.

In the analysis of the profile, it was still noticed a predominance of caregivers with a low level of education $35 \%$ studied 4 years or less and none of them had higher education, low financial power was also perceived, with a maximum income of 2 minimum salaries. This situation, although increasingly common, usually generates changes in the conformations of families. Literature is blunt when affirming that it is in the family that the main caregivers are found, since this is who recognizes the first signs and it is they who carry out the first care. However, changes in the health of an individual also trigger changes in the family dynamics, which can generate stress and crisis throughout the unit (INOUYE; PEDRAZZANI; PAVARINI, 2010; FREITAS et al., 2002).

Thus, there is a context in which daughters change their lifestyle to take care of their parents who were affected by the disease, starting to live according to their family. In some cases, it is necessary to abandon work and family, generating accumulation of work and overload which directly influences in all areas of the quality of life of these people (INOUYE; PEDRAZZANI; PAVARINI, 2010). As an example, a study shows that complaints of pain, stress, loss of sense of freedom, social isolation and decrease of the social support network in elderly caregivers are common.

The process of caring for the elderly with dementia is surrounded by challenges closely related to the progressive decline in cognition and social interaction behavior of the same (LUZARDO; WALDMAN, 2004). Inadequacies of one of the factors involved (elderly or caregiver) is pointed out in the literature as one of the important predictors for institutionalization of the individual with dementia (PINQUART; SÖRENSEN, 2006).

It is clear from the participants' speeches, how much they value the "normality" of their lives, without major stressors that may challenge their quality of life. In this sense, aggressive behavior was pointed out as one of the difficulties encountered by family caregivers.

A study carried out in a referral center in Alzheimer's disease care with 208 elderly caregivers of elderly people with AD in the city of Curitiba, Paraná, showed that caregivers are fearful due to the behavioral and personality changes of the elderly person with AD. They point out that these changes may pose risks to the well-being of both the caregiver and the elderly person (YEKTATALAB et al., 2013).

The care for an elderly person with $\mathrm{AD}$ usually is exhaustive considering that they are daily, exclusive and intense care requiring the caregiver much dedication. Thus, the routine of care provided is usually associated with the impossibility of visualizing changes in the subsequent days, generating a feeling of prison before the care and sadness of living life in the shadow of black and white (YEKTATALAB et al., 2013). The division between the life of the patient and that of the caregiver disappears, as the caregiver starts to intensely experience the life of his sick relative, so that nothing is lacking (INOUYE; PEDRAZZANI; PAVARINI, 2010).

Because of this intense routine, it is common for caregivers to deprive social life. In fact, even in ADL, care and intensive care is necessary due mainly to the progressive impairment due to the disease, the loss of autonomy and independence that result from it, as well as all cognitive alterations (FREITAS et al., 202).

Among these changes, the loss of recent memory is one of the first symptoms to manifest, and one that usually draws attention from family members. "Forgetfulness" usually appears in the early stages of the disease, and is accompanied by 
communication difficulties, whereas changes in long-term memory are characteristic only later in the course of the disease (YEKTATALAB et al., 2013; FREITAS et al., 2008).

The knowledge of family caregivers about Alzheimer's disease is limited and this can make it difficult to plan care for the elderly and to potentiate the caregiver's overload. Care is developed through a set of opinions and ways of feeling, imposed by the family tradition. They are generally accepted care in an uncritical way, coming from common sense (LENARDT et al., 2010).

This study has limitations. Because it is a qualitative study, generalizations that escape the universe of participants may not be possible. In addition, the possibility of information bias in the participants' speeches is highlighted.

It was evidenced in the speeches that the factors related to the QoL of the elderly caregiver with Alzheimer's, from the perspective of the caregiver is life in harmony, in which the caregiver is able to care for the elderly and to maintain their life with normality, working and solving their personal activities, without feel overwhelmed. They brought in their speeches that stressors can be configured as challenges to quality of life, especially regarding the behavior of the elderly with Alzheimer and the need to seek information about the disease, mainly referring to the symptoms of memory loss and functional disability of the elderly. The change in the caregiver's lifestyle and the impossibility of curing the illness and progressive development generate fear and changes in the family caregiver's lifestyle and financial burden, the tendency to isolation and decrease of social support network and the one who assumes the mission of caring ends up having a wear that interferes directly with the quality of life.

The care for the elderly with Alzheimer's is one of the great challenges of today, due to the rapid evolution of the disease, the irreversibility and lack of knowledge and preparation of the population, professionals and public and private services, this demand has been taking countries - mainly the developing countries - by surprise and they are not prepared to serve it.

The progressive loss of functional capacity makes it impossible for the elderly to develop their ADLs and IADLs, which makes them dependent on the care of others. In our study $95 \%$ of these caregivers were a family member, characterized as an informal caregiver because he was a lay person, not prepared in a educational institution to provide this care and not be paid for this service, the profile of these caregivers, 95\% were female (wife and daughter) who assumed this role for different reasons.

The care of the elderly with Alzheimer's had a great impact on the quality of life of the caregivers interviewed, there were many complaints of stress, chronic pain, lack of sleep, social isolation, lack of financial resources and other factors related to the behavior of the elderly that influenced care provided.

Through the reports of caregivers, we identified factors associated with quality of life from their perspective. They associate their quality of life with a range of factors (emotional, physical, financial, disease state in the elderly and the degree of caregiver knowledge about the disease), noting that non-harmony between these factors may be crucial to affect your personal and professional life, as well as your quality of life. It was noticed that the caregiver is required changes in his lifestyle, which allow him to donate more to the elderly. In addition, it is highlighted that deficits in the quality of life of the caregiver have shown great potential to compromise the care provided.

This study helps to answer a public health problem of great complexity, since Alzheimer's disease is a great challenge for the caregiver, who does not have a social support network strengthened and is isolated and fragile. Identifying the factors that affect the quality of life of the caregiver gives us support to create strategies to relieve overload, social interaction, access to knowledge and strengthen health services.

RESUMO: Este estudo teve como objetivo conhecer os fatores associados à qualidade de vida (QV) de cuidadores de idosos diagnosticados com doença de Alzheimer na perspectiva desses indivíduos. Foi um estudo descritivo, com abordagem qualitativa, baseado no método do Discurso do Sujeito Coletivo. Vinte cuidadores de idosos com diagnóstico de doença de Alzheimer participaram, durante um mês, no período de 18 de setembro a 18 de outubro de 2017. A coleta de dados foi realizada por meio de entrevistas com cuidadores de idosos com doença de Alzheimer. As perguntas foram feitas e gravadas em gravador, com a permissão do entrevistado. Os dados foram analisados pela Classificação Hierárquica Descendente (DHC). Foram obtidas cinco classes: Conceito de qualidade de vida do cuidador idoso; Comportamento do idoso com Alzheimer; Problemas de memória do idosos e repercussões no trabalho do cuidador; Mudança no estilo de vida do 
cuidador familiar; e Repercussão de "ser cuidador" na qualidade de vida. A QV esteve relacionada a uma série de fatores (emocional, físico, financeiro, estado da doença dos idosos e o grau de conhecimento do cuidador sobre a doença). Os cuidadores apontaram que a não harmonia entre esses fatores pode ser crucial para afetar sua vida pessoal e profissional, bem como sua QV.

PALAVRAS-CHAVE: Alzheimer. Cuidadores. Idosos.

\section{REFERENCES}

ADI - ALZHEIMER'S DISEASE INTERNATIONAL. World Alzheimer Report 2015: the global impact of dementia - an analysis of prevalence, incidence, cost and trends. London, 2015. Disponível em: http://www.alz.co.uk/research/world-report-2015

BRASIL. Instituto Brasileiro de Geografia e Estatística (IBGE). Censo demográfico 2010: características da população e dos domicílios - resultados do universo. Rio de Janeiro, 2011.

CARVALHO, E. B; NERI, A. L. Time use by family caregivers of elderly with dementia: an integrative review. Rev. Bras. Enferm., Brasília , v. 71, supl. 2, p. 893-904, 2018. Available from: http://dx.doi.org/10.1590/0034-7167-2017-0268.

CENSIS, L. B. La mente rubata. Bisogni e costi sociali della malattia di Alzheimer. $1^{\text {a }}$ ed. Franco Angeli, Milano: 1999.

COUTO, A. M.; CASTRO, E. A. B.; CALDAS, C. P. Vivências de ser cuidador familiar de idosos dependentes no ambiente domiciliar. Revista da Rede de Enfermagem do Nordeste, v. 17, n. 1, p. 76-85, ago. 2016. DOI: $10.15253 / 2175-6783.2016000100011$

FREITAS, E. V. et al. Tratado de geriatria e gerontologia. $1^{\mathrm{a}}$ ed. Guanabara Koogan, Rio de Janeiro: 2002.

FREITAS, I. C. C. et al. Living with the person who has Alzheimer's disease: perspectives of family caregiver. Revista Brasileira de Enfermagem, v. 61, n. 4, p. 508-13, jul/ago. 2008. http://dx.doi.org/10.1590/S003471672008000400018 .

ILHA, S et al . Complex educational and care (geron)technology for elderly individuals/families experiencing Alzheimer's disease. Rev. Bras. Enferm., Brasília, v. 70, n. 4, p. 726-732, Aug. 2017. Available from: http://dx.doi.org/10.1590/0034-7167-2016-0687.

INOUYE, K.; PEDRAZZANI, E. S.; PAVARINI S. C. I. Implications of Alzheimer's disease for the caregiver's quality of life: a comparative study. Cadernos de Saúde Pública, n. 26, v. 5, p. 891-99, mar. 2010. http://dx.doi.org/10.1590/S0102-311X2010000500011.

LEFEVRE, F.; LEFEVRE, A. M. C. O discurso do sujeito coletivo: um novo enfoque em pesquisa qualitativa. Educs, Caxias do Sul: 2003a.

LEFEVRE F.; LEFEVRE A. M. C. Pesquisa qualitativa levada a sério. São Paulo: 2003b. http://www.fsp.usp.br/ flefevre/Discurso_o_que_e.htm.

LENARDT, M. H. et al. Elderly with Alzheimer'sDisease: the care and the knowledge of the familial caregiver. Revista Mineira de Enfermagem, v. 14, n. 3, p. 301-7, jul. 2010 http://www.reme.org.br/artigo/detalhes/120.

LUZARDO, A. R.; WALDMAN, B. F. Atenção ao familiar cuidador do idoso com doença de Alzheimer. Acta Scientiarum. Health Sciences, v. 26, n. 1, p. 135-45, set. 2004. https://www.lume.ufrgs.br/bitstream/handle/10183/140057/000590924.pdf?sequence=1. 
MATOS, M.C.B et al. "Controle de Infecção é Sinal de Segurança": Discussões a partir da Perspectiva Discente. Revista de Pesquisa: Cuidado é Fundamental, v.10, n.3, p. 640-646, 2018. DOI: http://dx.doi.org/10.9789/2175-5361.2018.v10i3.640-646

MATOS, M.C., et al. Nursing professionals' knowledge regarding the management of waste produced in primary health care. Rev. Bras. Enferm., Brasília, v. 71, supl. 6, p. 2728-2734, 2018 . http://dx.doi.org/10.1590/0034-7167-2018-0308.

OLIVEIRA, L. B.; et al. Disposal of contaminated materials in primary health care: Nursing assistance grants. Rev Pre Infec e Saúde. v. 3, n. 1, p. 23- 28, 2017. https://doi.org/10.26694/repis.v3i0.6076

PEREIRA, L. S. M.; SOARES, S. M. Fatores que influenciam a qualidade de vida do cuidador familiar do idoso com demência. Caderno de Saúde Coletiva, v. 20, n. 12, p. 3839-51, abr. 2015. http://dx.doi.org/10.1590/1413-812320152012.15632014.

PINQUART, M.; SÖRENSEN, S. Helping caregivers of persons with dementia: which interventionswork and how large are their effects? International Psychogeriatrics, v. 18, n. 4, p. 577-95, maio. 2006. DOI: https://doi.org/10.1017/S1041610206003462

PRINCE, M.; et al. World Alzheimer Report 2014. Dementia and risk reduction: an analysis of protective and modifiable factors. Alzheimer's Disease International, v. 1, 2014.

PROCHET, T. C.; SILVA, M. J. P. Perception of the elderly in the view of affective behaviors expressed by the nursing team. Escola Anna Nery, v. 15, n. 4, p. 784-90, oct/dec. 2011. http://dx.doi.org/10.1590/S141481452011000400018 .

QUEIROZ, A.A.F.L.N; SOUSA, A.F.L. Fórum PrEP: um debate on-line sobre uso da profilaxia pré-exposição no Brasil. Cad. Saúde Pública, Rio de Janeiro, v. 33, n. 11, e00112516, Nov. 2017. http://dx.doi.org/10.1590/0102-311x00112516.

QUEIROZ, A.A.F.L.N et al. Knowledge about HIV/AIDS and implications of establishing partnerships among Hornet ${ }^{\circledR}$ users. Rev. Bras. Enferm., Brasília, v. 71, n. 4, p. 1949-1955, Aug. 2018 . http://dx.doi.org/10.1590/0034-7167-2017-0409.

RODRIGUES, P. S. et al. Occupational accidents among nursing professionals working in critical units of an emergency service. Escola Anna Nery, v. 21, n. 2, p. e20170040, abr. 2017. http://dx.doi.org/10.5935/14148145.20170040.

RODRIGUES, P. S et al. Acidente com material biológico: percepção dos profissionais de enfermagem de serviço de emergência. Rev Pre Infec e Saúde. v. 3, n. 2, p. 23-28, 2017. https://doi.org/10.26694/repis.v3i2.6448

SEIMA, M. D.; LENARDT, M. H.; CALDAS, C. P. Care relationship between the family caregiver and the elderly with Alzheimer. Revista Brasileira de Enfermagem, v. 67, n. 2, p. 233-40, mar/apr. 2014. http://dx.doi.org/10.5935/0034-7167.20140031.

SOUSA, M.; et al. Fatores associados à sobrecarga do cuidador: Estudo comparativo entre cuidadores brasileiros e espanhóis de pacientes com doença de Alzheimer (DA). International Psychogeriatrics, v. 28, n. 8 , p. 1363-1374, 2016. doi: 10.1017 / S1041610216000508

WHO - World Health Organization. Dementia: a public health priority. Geneva, 2012.

WHOQOL Group - World Health Organization Quality of Life Group. The World Health Organization Quality of Life assessment (WHOQOL): position paper from the World Health Organization, 1995. 
WOODWARD, M. Aspects of communication in Alzheimer's disease: clinical features and treatment options. International Psychogeriatrics, v. 25, n. 6, p. 877-85, mar. 2013.

https://www.ncbi.nlm.nih.gov/pubmed/23522497. https://doi.org/10.1017/S1041610213000318

YEKTATALAB, S. et al. Living with and Caring for Patients with Alzheimer's Disease in Nursing Homes. Journal of Caring Sciences, v. 2, n. 3, p. 187-95, ago. 2013.

https://www.ncbi.nlm.nih.gov/pmc/articles/PMC4134156/pdf/jcs-2-187.pdf. 